\section{Godt og mangfoldig om kroniske sår i huden}

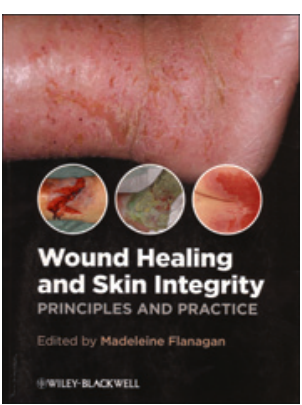

Madeleine Flanagan, red.

Wound healing and skin integrity

Principles and practice. $298 \mathrm{~s}$, tab, ill.

Chichester: Wiley-Blackwell, 2013.

Pris GBP 33

ISBN 978-0-470-65977-9

Dette er en innholdsrik lærebok om kroniske sår. Forfatterne innleder kort om helseforskning og avslutter med helseøkonomi. Hoveddelen er imidlertid klinisk med sårhelingsfysiologi, patogenese, anamnese og undersøkelse. Hovedgruppene av kroniske sår gjennomgås. De tar også opp psykologiske aspekter og ivaretakelse av hud ved de vanligste hudsykdommene som psoriasis og eksem.

Boken er i A5-format med myke permer, illustrert med fotografier, figurer og tabeller. Det er 17 kapitler som innledes med Overview og avsluttes med Summary. Kapitlene har også blå informasjonsbokser med viktige poenger og «practice point». Hvert kapittel har referanseliste og henvisning til aktuelle nettsteder.

Forfatterne har rettet søkelyset mot hovedgruppene av kroniske sår ved sirkulasjonbetingede sår, trykksår og diabetessår. Disse kapitlene er gode med oversikt over utredning og behandlingsforløp. Kompliserende faktorer i sårtilheling som infeksjoner, kontaktallergi og irritativ dermatitt behandles også. Øvrige sår fremstilles som sjeldne og spesielle. Forfatterne anbefaler henvisning til spesialist hvis det ikke er tegn til tilheling etter 12 uker. Dette er for de fleste typer sår en god regel. Det gis et noe kompliserende bilde av de mer sjeldne differensialdiagnosene enn nødvendig. Gangen i et vanlig utredningsforløp mangler, endog med fravær av biopsitaking. Som forfatterne understreker flere ganger, er riktig diagnose avgjørende. Utredning av et kronisk sår er ikke komplisert. Det dreier seg om sirkulatorisk undersøkelse, biopsi, testing av kontaktallergi (brukertest eller testpanel hos hudlege), orienterende blodprøve og mikrobiologiske prøver. Avvik fra dette lille knippet av utredning bør begrunnes.

Sårpleie påvirker tilhelingshastigheten. Ved kroniske sår har den normalt selvbegrensende inflammasjonsprosessen kommet ut av kontroll, og proteaser i sårvæsken ødelegger vekstfaktorer og nye celler. Det er viktig at dødt ved fjernes regelmessig. Forfatterne gir en god oversikt over hvilke metoder som finnes for dette, og de beskriver ulike typer moderne sårprodukter. De vektlegger at bruk av billige bandasjer nødvendigvis ikke er lønnsomt på sikt hvis oppsugingsevnen er dårligere. Dette vil bidra til at sårvæsken blir liggende $i$ såret med vedlikehold av inflammasjon som forlenger tilhelingstiden. Våte bandasjer gir i tillegg irritativ dermatitt, som kan gi opphav til nye sår.

Boken er gjennomgående godt skrevet og har tilfredsstillende kildehenvisninger. Innholdsmessig retter boken seg stedvis mest til pleiere, men kan anbefales alle som behandler pasienter med kroniske sår. Den egner seg også som støttelitteratur i undervisningen i sårpleie, i tillegg til i oppstartfasen av forskning på sårbehandling, både $\mathrm{i}$ et klinisk og helseøkonomisk perspektiv.

\section{Kristin Bergersen}

Hudavdelingen

Oslo universitetssykehus, Rikshospitalet

\section{Rus- og avhengighetsbehandling hos unge}

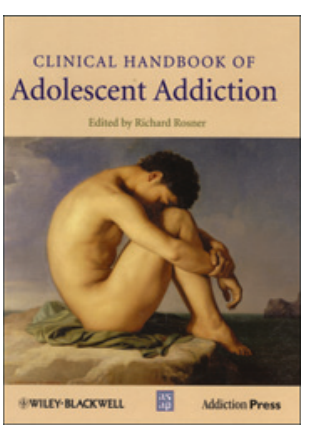

Richard Rosner, red

Clinical handbook of adolescent addiction 499 s, tab, ill. Chichester: Wiley-Blackwell, 2013. Pris GBP 55 ISBN 978-0-470-97234-2

Hvorfor en egen bok om rusproblemer hos ungdom? Jo, fordi en del problemer rundt rus er spesielle for ungdom: Deres hjerner er ikke fullt utviklet. De er impulsive og prøver seg på mange ting. Videre er de ikke juridisk ansvarlige, og man kan komme i etiske dilemmaer med hensyn til taushetsplikt o.l.

Dette og mer gjør at en bok om behandling av rusmiddelproblemer hos unge kan forsvares. Denne boken dekker imidlertid ikke bare det som er spesielt for ungdom, men ønsker å være en utfyllende bok for dem som arbeider med ungdom og rus. Dette er et fortjenstfullt mål, og det har redaktøren langt på vei lyktes med.

Boken er skrevet med utgangspunkt i den psykiatriske spesialiteten. Det betyr ikke at man trenger å jobbe innenfor psykiatrien eller ha stor psykiatrisk kunnskap for å ha glede av den, men vinklingen er mye rettet mot dobbeltdiagnoser og psykisk sykdom.

Først vil jeg nevne noen av svakhetene. Noe av det som er spesielt for ungdom, er forskjellig fra land til land, blant annet ting som ligger opp mot lovgivning. Når alle forfatterne unntatt seks er fra USA, blir noe av innholdet uaktuelt for norske klinikere. Jeg savner også en mer omfattende redigering. Boken fremstår ikke som en antologi, men noe blir litt tilfeldig. For eksempel er det meste av kunnskapen hentet fra amerikansk virkelighet, mens epidemiologien er hentet fra Storbritannia. Boken er delt i sju seksjoner med egne seksjonsredaktører og har 47 kapitler. Det er i alt 76 bidragsytere, noe som gir stor variasjon i form og innhold. Noe er direkte nyttig i klinisk arbeid, mens annet er av mer akademisk interesse. Slik må det bli (til redaktørens fortvilelse?) i en bok med så mange bidragsytere.

Boken er derfor ikke en håndbok, men den er en god oppslagsbok for feltet med et relativt godt stikkordregister. Det er nok slik en kliniker vil bruke den. Den er også egnet som lærebok for studenter, som kan finne mye nyttig. Det er imidlertid få tabeller og figurer, og i en verden hvor illustrasjoner er allestedsnærværende, inneholder denne boken påfallende mye løpende tekst og blir dermed litt tung å lese.

Men så er også svakhetene nevnt. Her er mye godt stoff om hvordan oppdage og evaluere ungdom med rusmiddelproblemer. Videre er det mye bra om dobbeltdiagnoser. Det er kapitler om forebygging og om de ulike rusmidlene. Det er også gode behandlingskapitler. Til slutt finnes en god seksjon om påvirkning av den unge hjernen, om traumer og avhengighet og om seksuell avhengighet og Internett-problemer.

\section{Jørgen G. Bramness}

Senter for rus og avhengighetsforskning (SERAF)

Universitetet i Oslo 